\title{
Hubungan Parasosial dan Perilaku Loyalitas Fans dalam Fandom KPop di Indonesia
}

\author{
Pulung S. Perbawani' ${ }^{1}$, Almara J. Nuralin² \\ 1 Universitas Gadjah Mada \\ Email: psperbawani@gmail.com \\ 2Universitas Gadjah Mada \\ Email: jatialmara@gmail.com
}

\begin{abstract}
ABSTRAK
Riset ini merupakan upaya untuk mengaji fandom sebagai sebuah fenomena ilmu komunikasi melalui perspektif interdisipliner, khususnya dalam kaitannya dengan disiplin psikologi komunikasi dan perilaku konsumen. Peneliti berupaya untuk menginvestigasi korelasi antara hubungan parasosial (Parasocial relationship/PSR) dan perilaku loyalitas fans, khususnya perilaku konsumsi terhadap brand dan produk yang terasosiasikan dengan idola mereka. Penelitian akan dilaksanakan menggunakan metode survei, dengan PSI Process Scale untuk mengukur variabel hubungan parasosial, dan commitment model untuk mengukur perilaku loyalitas fans. Kuesioner yang disebarkan secara online kemudian menghasilkan 271 kuesioner valid yang kemudian dianalisa dengan menggunakan analisis Mean, uji korelasi, dan analisis krostabulasi. Hasil penelitian menunjukkan bahwa terdapat hubungan yang signifikan antara hubungan parasosial dengan loyalitas fans. Hasil penelitian juga menunjukkan bahwa hubungan yang paling erat ditunjukkan oleh dimensi dimensi behavioral dengan dimensi interaction, sedangkan hubungan dengan nilai terendah ditunjukkan oleh hubungan antara dimensi perceptual-cognitive dengan desire to acquire.
\end{abstract}

Kata Kunci: parasosial, perilaku loyalitas, fanatisme, fandom, Kpop

\begin{abstract}
This paper investigates fandom as a phenomenon of communication science through an interdisciplinary perspective, especially in relation to the psychology discipline of communication and consumer behavior. The researcher seeks to investigate the correlation between parasocial relationships (Parasocial relationships/PSR) and fan loyalty behavior, specifically the consumption behavior of the brands and products associated with their idols. The research will be carried out using survey methods, with PSI Process Scale to measure parasocial relationship variables, and commitment models to measure fan loyalty behavior. From the questionnaires distributed online, 271 valid questionnaires were obtained which were analyzed using mean analysis, correlation test, and cross tabulation analysis. The results showed that there was a significant relationship between parasocial relationships and fan loyalty. The results also show that the closest relationship is shown by the behavioral dimension with the interaction dimension, while the relationship with the lowest score is shown by the relationship between the perceptual-cognitive dimension and desire to acquire.
\end{abstract}

Keyword: parasocial relationship, loyalty behaviour, fanaticism, fandom, KPop

\section{PENDAHULUAN}

Konsep interaksi parasosial telah banyak dikaji dalam media dan literatur komunikasi dalam empat dekade sejak kemunculan pertamanya oleh Horton dan Wohl (1956). Interaksi parasosial dapat dipahami sebagai "simulacrum of conversational give-and-take" (Horton \& Wohl, 1956, p. 215) yang terjadi selama situasi pemaparan media antara pengguna dan karakter 
yang dimediasi media, misalnya, pembawa acara TV. Hubungan ini merupakan ilusi yang ditimbulkan oleh media. Namun, semenjak perkembangan media baru dan kelahiran media sosial maka hubungan antara fans dan selebritas menjadi lebih intim (Marwick \& Boyd, 2011).

Hubungan parasosial dirasakan sebagai hubungan interpersonal antara dua pihak. Namun kebanyakan hal ini hanya dirasakan satu sisi karena tidak ada timbal balik yang terjadi dan karakter yang ada di media pada dasarnya tidak mengetahui keberadaan pihak lain, dalam hal ini fans. Persona di media ini juga tidak memiliki kewajiban untuk memelihara hubungan parasosial yang terbentuk dengan pemirsanya (Chung \& Cho, 2014).

Horton dan Wohl (1956) berpendapat, ikatan keintiman berkembang dengan media personalities melalui pengalaman yang dicapai melalui interaksi dengan persona sang media personality dari waktu ke waktu. Seiring berjalannya waktu, fans merasa mempunyai keakraban dengan persona tersebut. Para pengguna merasa bahwa hubungan parasosial mereka dengan selebritas bersifat tatap muka dan interpersonal (Horton \& Wohl, 1982). Hal ini, berimplikasi pada rasa keintiman antara fans dan persona media meningkat.

Hubungan parasosial dianggap mulai muncul ketika fans merasa bahwa mereka adalah teman dari karakter yang ada di media. Perasaan pertemanan ini yang kemudian menjadi faktor penting dalam mengembangkan hubungan parasosial daripada hubungan interpersonal yang dilakukan secara tatap muka. Kontak yang dilakukan secara berkala kemudian akan menyebabkan audiens berpikir mereka memiliki kedekatan dengan persona media tersebut. Hal ini kemudian semakin meningkatkan akurasi pemahaman audiens mengenai karakter media tersebut termasuk gaya, kepribadian, preferensi, dan kehidupan pribadi, terakumulasi, serta interpretasi dan pemahaman makna perilaku karakter (di atas panggung) (Chung \& Cho, 2014). Ini kemudian memberikan kesan bahwa audiens memahami secara penuh karakter media tersebut.

Horton dan Wohl (1956) mengemukakan bahwa hanya dengan menonton program televisi telah merupakan suatu bentuk atas peran parasosial. Setelah program berakhir, pemirsa akan menganalisis peran untuk menerima, menolak, atau lebih jauh menafsirkan proposisi interaksi parasosial dengan persona. Koneksi semacam itu memungkinkan pengguna merasa bahwa mereka menikmati hubungan interpersonal dengan kepribadian/selebritas media favorit mereka; koneksi tampaknya sangat intim sehingga pengguna merasa bahwa selebritas adalah teman pribadi, figur ayah, saudara kandung, atau bahkan kekasih (Hung, Chen, \& Tse, 2011). Mereka terpikat dengan nilai yang dibawa oleh persona media dan sering melihatnya sebagai penasihat, penghibur, bahkan sebagai panutan (Horton \& Wohl, 1982). Singkatnya, interaksi parasosial, adalah tentang perasaan ilusi pengguna berada dalam interaksi sosial timbal balik dengan karakter lain sementara sebenarnya berada dalam situasi non-timbal balik satu sisi, pendekatan yang secara tradisional berfokus pada media non-interaktif seperti televisi (Hartmann, 2016).

Interaksi parasosial merupakan interaksi yang terbentuk antara konsumen dan selebriti melalui saluran yang dimediasi (Shoffner, 2019). Hubungan parasosial terkadang dipandang sebagai hubungan khayalan yang dialami oleh fans yang mengidolakan sosok selebriti dan terjadi secara satu arah yaitu dari fans ke selebriti tersebut (Sitasari, Rozali, Arumsari, \& Setyawan, 2019). Teori parasosial didasarkan pada hubungan virtual antara selebriti dan fansnya, tetapi hubungan ini diintimasikan sebagai hubungan interpersonal yang dianggap nyata oleh para penggemar (Sokolova \& Kefi, 2020). Hubungan parasosial dianggap satu arah karena biasanya fans yang berada di rentang usia remaja dan dewasa muda ini merasakan kedekatan dengan selebriti idola mereka sedangkan sang selebriti sama sekali tidak mengenal mereka (Sulianti, Lubis, Az-Zahra, \& Hambali, 2018). Hubungan parasosial memungkinkan para konsumen tersebut untuk mengidentifikasikan dirinya dengan para selebriti, baik melalui sikap atau perilaku, hal ini kemudian memberikan peluang bagi selebriti untuk memberikan pengaruh terhadap audiensnya (Chung \& Cho, 2017). Hubungan parasosial mungkin menyebabkan timbulnya tingkat empati yang tinggi dari fans ke selebriti (Frederick, Lim, Clavio, \& Walsh, 2012).

Interaksi parasosial tidak identik dengan hanya mengamati karakter di layar (Horton \& Wohl, 1956, p. 215 dalam Hartmann, 2016). Sebaliknya, interaksi parasosial berkaitan dengan 
perasaan ilusi langsung pengguna berada dalam interaksi sosial nyata dengan karakter media, meskipun mengetahui bahwa mereka tidak (Hartmann \& Goldhoorn, 2011; Dibble, Hartmann, \& Rosaen, 2016; Horton \& Wohl, 1956). Terlepas dari kenyataan bahwa dalam perjumpaan parasosial peran komunikasi tidak berubah karena yang dimediasi lainnya selalu mempertahankan peran pengalamat dan pengguna selalu berperan sebagai penerima, pengguna tetap mengalami pertemuan itu sebagai "langsung, pribadi, dan timbal balik" (Horton \& Strauss, 1957, p. 580 dalam Hartmann, 2016, p. 132).

Interaksi dan hubungan parasosial berbeda dalam banyak aspek. Interaksi parasosial dapat dipahami sebagai ilusi berada dalam interaksi sosial timbal balik (meskipun tidak ada), sedangkan interaksi sosial yang dikembangkan pengguna terhadap karakter media sebagai ilusi tidak perlu dilakukan (pengguna mungkin sepenuhnya sadar akan interaksi sosialnya). Lebih lanjut, interaksi parasosial dimulai oleh dan, oleh karena itu, memerlukan kehadiran orang lain yang dimediasi, sedangkan hubungan parasosial dapat dialami dan juga terus ada bahkan jika orang yang dimediasi tidak ada.

Lebih jauh, interaksi parasosial tidak secara inheren positif atau negatif dan dapat dirasakan sama terhadap orang-orang yang dimediasi yang disukai atau tidak disukai. Sebaliknya, hubungan parasosial dapat didefinisikan dan dibedakan berdasarkan valensinya (mis., Pertemanan lawan antipati). Interaksi parasosial dan hubungan parasosial dipicu oleh factor-faktor yang berbeda-Interaksi parasosial dengan bentuk pengalamatan seperti tatapan mata, hubungan parasosial yang positif dengan pihak lain yang dimediasi yang menampilkan sifat atau perilaku menarik yang memicu keinginan.

Terdapat beberapa konsep yang dapat digunakan untuk mengukur hubungan parasosial. Salah satunya adalah skala PSI (parasocial interaction) dan skala EPSI (Experience of Parasocial Interaction). Namun, kedua skala tersebut mengukur hubungan parasosial dan tidak mengukur proses parasosial yang terjadi. Adapaun skala yang mengukur proses parasosial adalah PSIprocess yang pertama diperkenalkan oleh Schramm dan Hartmann (2008). Proses parasosial (parasocial processing) dapat diartikan sebagai "the degree to which the individual interacts psychologically with a media character" (Schramm \& Hartmann, 2008, p. 388). PSI-process scale merupakan skala yang dianggap lebih baik karena memberikan penekanan kepada pengukuran PSI daripada aspek teori parasosial lainnya (Stever, 2017). Lebih jauh, PSI-process scale telah diaplikasikan kepada berbagai jenis karakter media mencakup teater, opera sabun, dan pertunjukan kuis, yang kemudian menunjukkan bahwa skala ini valid untuk diterapkan di berbagai konteks media (Rasmussen, 2018). Riset mengenai PSI sebagai parasocial processing penting untuk mengetahui proses resepsi dari audiens.

PSI (parasocial interaction), sebagaimana dimaknai sebagai proses parasosial (parasocial processing), termanifestasi dalam berbagai bentuk di antaranya adalah: intensive thoughts deliberations, tense body movements, agile facial expressions and gestures, dan speaking to the persona that is displayed on the TV screen (Schramm, 2015, p. 438). PSI dapat diklasifikasikan, sama halnya seperti involvement, sebagai sebuah meta-concept yang terdiri dari: "attention, knowledge activation, evaluation, social comparison, sympathy, empathy and emotional contagion" (De Guzman Centeno, 2016, p. 445). Model ini digunakan untuk mengukur proses parasosial yang terjadi ketika audiens terpapar dengan persona media. Kesimpulannya, PSI sebagai sebuah proses parasosial adalah tentang bagaimana audiens merespon karakter media secara kognitif, afektif, dan behavioral. Menurut klasifikasi psikologi, model ini membedakan beberapa hal, di antaranya: (1) perceptual-cognitive, (2) affective, dan (3) respon behavioral terhadap persona.

Dalam kajian fandom budaya populer, PSI dapat digunakan sebagai sebuah parameter dalam mengukur dan menjelaskan fanatisme dan keterlibatan para fans dengan idola mereka. Fanatisme adalah bentuk unik dari investasi dalam ketertarikan terhadap sebuah objek, yang dikarakterisasikan oleh level loyalitas, komitmen, kesetiaan, pengabdian, hasrat, keterikatan emosional, antusiasme, dan keterlibatan (Seregina, 2011) Fenomena fanatisme dinilai mempengaruhi perilaku sosial dalam cakupan tertentu, termasuk perilaku konsumen melalui adanya berbagi kepercayaan, makna, dan pengalaman (Kozinets, 1997 dan Thorne \& Bruner, 2006; dalam Seregina, 2011). 
Fanatisme kemudian dinilai memiliki konsep yang serupa dengan konsumen dimana memiliki relasi brand, loyalitas, pengabdian, keterikatan, dan bahkan cinta. Melaui fanatisme, penggemar memiliki ikatan kuat dengan idolanya selayaknya hubungan interpersonal dimana berkaitan erat dengan konsep identitas diri yang didominasi oleh hasrat dan emosi sehingga perilaku yang dilakukan oleh penggemar pada dasarnya merupakan bentuk perilaku emosional (Seregina, 2011).

Menurut Caughey (1984 dalam (Jenol \& Pazil, 2020, p. 336) "the basis of most fan relationships is not an aesthetic appreciation but a social relationship. Fans have attachments to unmet media figures that are analogous to and in many ways directly parallel to actual social relationships". Lebih jauh menurut Samra dan Wos "fans possess a strong and intense emotional attachment with the consumption objects." (2014, p. 265). Selain itu, keterlibatan seorang fans tidak hanya secara emosional tetapi juga keterlibatan secara intelektual. Dalam hal ini, "emotional affiliation has been used to distinguish the fan from general consumers" (Samra \& Wos, 2014, p. 265). Grossberg (dalam Samra \& Wos, 2014, p. 265) mengamati bahwa "a fan is more closely associated with a particular form of intensity or affect compared to general customers." Lebih lanjut, Samra dan Wos (2014, p. 265) menyebutkan bahwa "fans present informal membership behaviours, such as co-production and investment." Hubungan yang dibangun oleh fans dan objek minat "tends to always be active and proactive." Partisipasi aktif yang terjadi pada proses produksi oleh fans berbeda dari konsumen pada umumnya. Dalam konteks fans televisi, (Jenkins dalam dalam Samra \& Wos, 2014, p. 265) ditemukan bahwa "some media fans as consumers who also produced, such as readers who also wrote, and spectators who also participated." Grossberg (dalam Samra \& Wos, 2014, p. 265) lebih lanjut membahas bahwa "fandom creates something more than consumption of cultural objects and actively produces views on the objects." Berbagai bentuk keterlibatan fans tersebut kemudian memunculkan budaya partisipatif diantara mereka (Jenol \& Pazil, 2020). Ini terjadi seiring dengan perkembangan teknologi, sehingga komunitas penggemar semakin tersebar luas melewati batas negara, etnis dan penyebarannya berbasis internet (Groene \& Hettinger, 2016).

Samra \& Wos (2014, p. 265) menyebutkan bahwa "fans behave as loyal consumers who exhibit several loyalty behaviours, such as repeating their purchase or patronage, or insisting on staying in the relationship between brands or products." Konsumsi teratur dan berulang menjadi indikator penting dari investasi emosional tertentu seorang fans. Sandvoss (dalam Samra \& Wos, 2014, p. 265) mengamati bahwa "most of those who labelled themselves as fans, pointed to their repeated consumption patterns." Definisi fandom yang dikemukakan oleh Sandvoss didasarkan pada "repeated consumption and emotional bond with the fanatic objects and his description of the fan equates with consumer loyalty behaviour." "Such loyal behaviour is a composite blend of brand, an attitude, and behaviour with indexes that measure the degree to which the consumer favours and purchases a brand repeatedly" (Day, 1969; Pritchard \& Howard, 1997 dalam Samra \& Wos, 2014, p. 265).

Fandom kemudian diargumentasikan sebagai ekspresi dari fenomena yang lebih besar berkaitan dengan fanatisme terkait konsumsi dan terkait merek yang ada di masyarakat modern saat ini (Fuschillo, 2020). Fanatisme memberikan konsumen tersebut sumber makna untuk mengkonstruksikan identitas mereka. Ini kemudian mendorong fans untuk melakukan konsumsi yang berkaitan dengan fandom. Fanatisme konsumen didefinisikan sebagai " $a$ consumer's extraordinary pursuit of a consumption object (i.e. a product, brand, ideology, experience), driven by an affective commitment, where affective commitment is a voluntary and volitional conscious decision to pursue (continue pursuit of) the object of fanaticism, and extraordinary implies going beyond the ordinary, usual, or average levels in its pursuit" (Chung, Farrelly, Beverland, \& Karpen, 2017, p. 15). Hal tersebut kemudian menunjukkan bahwa fans yang melakukan konsumsi atas dorongan fanatisme merupakan fans yang memiliki suatu bentuk loyalitas terhadap merek tertentu.

Oleh Seregina (2011, p. 14-16) perilaku loyalitas yang terkait dengan karakteristik fanatisme didefinisikan ke dalam empat aspek, yaitu internal involvement, external involvement, desire to acquire dan interaction. Internal involvement merujuk kepada kondisi dimana fans memfokuskan waktu, energi, dan sumber daya mereka dengan cermat kepada bidang minat 
tertentu. External involvement menggambarkan situasi behavioral yang berorientasi sosial, relatif dengan bidang minat tertentu. Desire to acquire adalah karakter dimana fans memiliki hasrat yang kuat untuk mendapatkan dan mengumpulkan objek kepemilikan yang berhubungan dengan bidang minat mereka. Sedangkan interaksi merujuk kepada hasrat akan interaksi sosial (Thorne \& Burner, 2006 dalam Seregina, 2011, p. 14-15).

Lebih lanjut, Loyalitas terhadap suatu objek (mis. brand, toko, layanan, atau perusahaan) ditunjukkan oleh kecenderungan memilih objek tersebut, kecenderungan ini tercermin dari perilaku dan sikap konsumen. Dalam konteks marketing, loyalitas dapat dikatakan sebagai brand retention (mis. Reichheld, 1996; Reinartz \& Kumar, 2000). Brand loyalty umumnya dikonotasikan atau diartikan sebagai "the biased (non-random) behavioral response (purchase) expressed over time by some decision-making unit with respect to one or more alternative brands out of a set of rands and is a function of psychological processes" (Jacoby, 1971, dalam (Han, et.al, 2018, p. 89). Brand loyalty kemudian menjadi fokus dalam strategi perusahaan yang diterapkan di perusahaan dan mencakup 6 dimensi utama yaitu niat patronase ulang, tingkat kepuasan, preferensi merek, harga premium, biaya peralihan, dan komitmen merek (Han, et.al , 2018).

Oliver (1999 dalam Abu-Alhaija, Hussein, \& Allan, 2019, p. 29) mendefinisikan loyalty sebagai "a deeply held commitment to re-buy or re-patronise a preferred product/service consistently in the future, thereby causing repetitive same-brand or same brand-set purchasing, despite situational influences and marketing efforts having the potential to cause switching behavior." Dengan kata lain, loyalitas dapat didefinisikan sebagai sebuah tendensi konsumen untuk memilih salah satu produk dibanding produk lainnya. Selanjutnya, Jacoby \& Chestnut (1978 dalam Hoffmann, 2013, p. 22) dengan jelas mengatakan bahwa brand loyalty merupakan "a function of psychological (decision-making, evaluative) processes exhibited over time" yang merupakan definisi condong kepada pengertian psikologi dari loyalitas itu sendiri. Loyalitas merupakan konsep multidimensional dimana hal ini mengaitkan niat pembelian di masa depan, loyalitas afektif dan loyalitas kognitif dengan mempertimbangkan sesuatu secara khusus sebagai satu-satunya acuan untuk perilaku pembelian di masa depan (Picon, Castro, \& Roldan, 2014).

Brand loyalty merupakan aset fundamental bagi sebuah brand. Dalam sebagian besar brand equity, brand loyalty diasumsikan sebagai salah satu komponen (Aaker, 1991 ) atau hasil dari brand equity (Erdem \& Swait, 1998). Wilkie (1994) mendefinisikan brand loyalty sebagai sikap yang menguntungkan terhadap, dan pembelian konsisten, brand tertentu. Aaker (1991) mengindentifikasi loyalitas sebagai kunci penentu pilihan dan ekuitas. Menurut Kotler dan Keller (2012), loyalty pelanggan adalah elemen fundamental dan esensial yang utama dalam membentuk brand yang benar-benar kuat. Oleh karena itu, brand seringkali mengusahakan "systematic and well-assisted development of loyalty behaviors among their costumers" (Alok \& Srivastava, 2013, p. 140). Fondasi ini tidak hanya berlaku pada brand sebagai sebuah perusahaan namun juga brand selebritas. Semakin besar brand loyalty yang dimiliki selebritas maka akan semakin kuat fondasi popularitas yang didapat dari penggemar.

Perkembangan penelitian mengenai brand loyalty kemudian mendorong konseptualisasi dan pengukuran untuk menjadi semakin kompleks. Pada awalnya loyalitas suatu merek dianggap sebagai ukuran satu dimensi yang berkaitan dengan perilaku atau pembelian atau tindakan yang menunjukkan loyalitas. Perkembangan konsep loyalitas kemudian menyebabkan ditambahkannya dimensi sikap dalam melakukan pengukuran. Hal ini kemudian menyebabkan pengukuran loyalitas dilihat dari dua hal yaitu sikap dan perilaku yang loyal. Sehingga kemudian sikap loyal dan perilaku loyal dianggap sebagai dua konstruksi berbebeda yang membangun loyalitas merek. Perkembangan terakhir dari konsep loyalitas kemudian menambahkan dimensi kognitif, yang digunakan bersamaan dengan sikap dan perilaku, untuk melakukan pengukuran loyalitas (Ehsan, Warraich, \& Sehribanoglu, 2016).

Penelitian yang dilakukan oleh Labrecque (2014) menunjukkan bahwa hubungan parasosial antara merek dan konsumen akan menghasilkan loyalitas merek. Ini disebabkan ketika konsumen memandang bahwa terdapat interaksi yang erat dan keterbukaan komunikasi antara merek dan konsumen maka kekuatan hubungan parasosial dengan merek tersebut akan meningkat. Loyalitas yang berkaitan degan hubungan antara fans dan selebriti dapat diartikan sebagai dedikasi fans untuk membeli produk atau layanan yang berkaitan dengan selebriti 
favorit mereka (Kim \& Kim, 2020). Penggemar cenderung melakukan pengulangan dalam perilaku positif yang berkaitan dengan selebriti dalam jangka waktu tertentu (Kim \& Kim, 2017). Loyalitas kepada selebriti tersebut kemudian membentuk attitudinal loyalty (Kim \& Kim, 2020). Dalam hal ini kemudian terdapat kecenderungan fans untuk memiliki disposisi yang baik terhadap selebriti. Lebih lanjut menurut Audi, Masri dan Ghazzawi (2015), attitudinal loyalty tersebut dapat mengarahkan dan kemudian mencapai aspek behavioral loyalty di masa mendatang. Sehingga kemudian loyalitas fans menjadi condong ke selebriti favorit mereka yang diekspresikan sebagai perilaku positif yang ditunjukkan dari waktu ke waktu, misalnya dengan melakukan pembelian barang-barang yang berkaitan dengan selebriti tersebut.

Dinilai dari permukaan, bentuk perilaku emosional dari penggemar kemudian dipandang serupa dengan perilaku konsumtif yang kompulsif. Namun, Seregina (2011) menjabarkan bahwa perilaku konsumsi yang kompulsif ataupun fanatis pada dasarnya memiliki karakter yang berbeda. Konsumsi kompulsif diartikan sebagai perilaku adiktif dan ketergantungan psikologis yang sering dihubungkan dengan perasaan negatif dimana bentuk konsumsi yang dilakukan sering kali sebagai bentuk 'pelarian' atau reaksi dari situasi yang tidak menyenangkan. Sedangkan fanatisme lebih kepada perasaan adiktif dan perilaku obsesif yang berangkat dari perasaan positif karena yang dicari bukan 'pelarian', melainkan kepuasan, penemuan jati diri, dan perasaan memiliki. Baik perilaku kompulsif atau fanatisme dapat dilihat sebagai bentuk perilaku yang tampak sama dari permukaan karena faktor pembedanya bersifat psikologis, yaitu motif, makna, dan perasaan.

Lantas, jika hubungan idola dan fans paralel dengan hubungan brand dan konsumen, serta hubungan parasosial menjelaskan mengenai keterlibatan (dan potensi loyalitas) antara keduanya, sejauh manakah hubungan parasosial dapat berpengaruh terhadap loyalitas?

Sebagai sebuah industri, KPop sebagai sebuah klasifikasi besar mewakili konsep pengelolaan industri musik dan idola yang profesional, terorganisir, dan berorientasi kepada konsumen, melebihi industri budaya pop dari negara atau kawasan lain. Kelompok-kelompok musik Kpop merupakan brand yang mewakili tidak hanya produk musik saja, melainkan added value yang berupa konsep, narasi, serta pengalaman emosional. Tidak heran jika brand yang masuk dalam kategori Kpop mampu membangun keterikatan emosional yang jauh lebih tinggi dengan konsumen, dalam kasus ini fans mereka. Kelompok musik idola Kpop, baik sebagai brand yang independen maupun yang terasosiasi dengan brand lain sebagai ambassador, dapat mempengaruhi massanya dalam mengkonsumsi produk/brand yang dikomunikasikannya.

Artikel ini merupakan hasil investigasi korelasi antara hubungan parasosial (parasocial relationship/PSR) dan loyalitas fans sebagai konsumen dari idola mereka. Dengan menggunakan parasocial interaction scale, penelitian ini bertujuan untuk menjelaskan sedalam apa hubungan parasosial antara idola dan fans, dan pengaruhnya terhadap perilaku loyalitas konsumen.

\section{METODE PENELITIAN}

Artikel ini disusun berdasarkan data yang diperoleh melalui survei eksplanatori. Metode ini dipilih karena mampu menjelaskan korelasi antara dua variabel, yaitu Parasocial Relationship Index dan loyalty behaviour.

Populasi dalam penelitian ini adalah fans K-pop Indonesia dan sampelnya adalah fans K-pop yang menggunakan media sosial untuk mengakses konten K-pop. Adapun kriteria dari responden yang dipilih dalam penelitian ini adalah fans Kpop berusia 13-39 tahun. Kuesioner disebarkan kepada responden, dengan menerapkan prinsip non-probability sampling. Kuesioner disebarkan melalui akun-akun fanbase K-pop di media sosial seperti Twitter, Facebook, maupun Instagram.

Dari kuesioner yang disebar, didapatkan 271 kuesioner valid yang kemudian diolah secara statistik. Peneliti menanyakan fandom responden dan lamanya responden tergabung di dalam fandom tersebut. Jumlah terbanyak adalah mereka yang tergabung di dalam fandom BTS sebesar $24,7 \%$ dan paling banyak adalah mereka yang tergabung selama 2 tahun yaitu sebanyak $20,3 \%$. Mayoritas responden adalah perempuan $(94,8 \%)$, dengan usia terbanyak di angka 22 tahun (25\%), tingkat pendidikan SMA/sederajat (50,6\%) dan S1/sederajat $(39,1 \%)$. 
Validitas kuesioner diukur dengan menggunakan Pearson Correlation Test dengan $r$ tabel 0,361 . Hasil menunjukkan bahwa rhitung yang didapatkan adalah 0,383 yang lebih rendah dari rtabel sehingga instrumen dinyatakan valid. Sedangkan reliabilitas instrumen kuesioner diuji dengan menggunakan Cronbach Alpha yang jika menunjukkan nilai > 0,6 maka instrumen penelitian dianggap reliabel. Hasil menunjukkan nilai 0,953 sehingga instrumen dianggap reliabel. Analisis data akan dilakukan dengan menggunakan analisis Mean, uji korelasi, dan analisis krostabulasi.

\section{HASIL DAN PEMBAHASAN}

\section{Analisis Mean}

1. Parasosial

a. Perceptual-cognitive

Pernyataan "Saya memahami aspek kepribadian bias saya yang sangat saya sukai atau tidak saya sukai" memiliki nilai mean tertinggi pada dimensi perceptual-cognitive dengan nilai sebesar 4,03. Artinya, responden cenderung menyetujui pernyataan tersebut. Dari sini bisa dikatakan bahwa responden bisa membedakan mana sifat dari idola mereka yang baik dan buruk.

Sementara pernyataan "Kadang-kadang, saya penasaran jika bias saya mirip dengan saya atau tidak" mendapat nilai mean terendah di antara pernyataan lain sebesar 3,00 yang berarti bahwa responden cenderung ragu-ragu akan pernyataan ini. Dengan kata lain, responden cenderung tidak terlalu peduli apakah mereka mirip dengan idola mereka atau tidak.

\section{b. Affective}

Pernyataan yang memiliki nilai mean paling tinggi adalah "Saya menyukai bias saya karena prestasi mereka” dengan nilai mean sebesar 4,60. Artinya, responden cenderung menyetujui pernyataan tersebut. Prestasi idola membuat para responden bangga pada idola mereka dan responden akan merasa senang karena sudah mengidolakan.

Sementara pernyataan dengan mean terendah adalah pernyataan "Bias saya mengubah hidup saya" dengan nilai 3,78 yang berarti responden juga cenderung setuju dengan pernyataan tersebut. Karya-karya dari idola sedikit banyak berisikan kisah inspiratif dan motivasi yang membangun. Tak jarang responden akan merasa bahwa pesan yang dibawa oleh idola mereka sesuai dengan kisah hidup mereka. Pada akhirnya, pesan tersebut membawa perubahan yang signifikan dalam hidup responden.

\section{c. Behavioral}

Pernyataan dengan nilai mean tertinggi pada dimensi behavioral adalah pernyataan "Ada banyak hal yag ingin saya bicarakan dengan bias saya" dengan nilai mean sebesar 4,06. Para responden cenderung menyetujui pernyataan tersebut. Mengidolakan seseorang berarti kita memiliki rasa kagum kepada orang tersebut. Seperti pada dimensi afektif, idola bisa saja mengubah hidup responden. Responden mungkin ingin menyatakan kekaguman atau rasa terima kasih kepada sang idola karena telah membawa perubahan baik dalam hidup responden.

Pertanyaan dengan nilai mean terendah adalah "Kadang-kadang, saya tanpa sadar saya mengucapkan sesuatu yang tertuju kepada bias saya" dengan nilai mean sebesar 3,38. Para responden juga memiliki kecenderungan untuk menyetujui pernyataan ini. Ada kalanya responden membayangkan bertemu dengan idola mereka dan secara spontan mengucapkan halhal yang ingin mereka bicarakan kepada idola mereka meskipun tidak bertemu langsung dengan sang idola.

\section{Perilaku Loyalitas}

a. Internal involvement

Pada dimensi ini, pernyataan yang memiliki nilai mean tertinggi adalah "Melakukan aktivitas fandom K-pop membuat saya senang" dengan nilai mean sebesar 4,26 yang berarti responden cenderung setuju. Sementara penyataan dengan nilai mean terendah adalah "Saya 
sering memilih meninggalkan kewajiban dunia nyata saya untuk melakukan aktivitas fandom" yaitu sebesar 2,14 di mana responden cenderung tidak setuju.

Dunia fandom K-pop bisa dikatakan sebagai dunia tempat pelarian responden dari dunia nyata. Responden bisa mendapatkan konten-konten menarik tentang idola dan membawa kesenangan kepada mereka. Meskipun dunia fandom merupakan pelarian dari dunia nyata, responden tidak bisa serta merta melepaskan urusan mereka di kehidupan nyata. Melakukan aktivitas fandom hanya dilakukan ketika responden sedang jenuh dan butuh hiburan saja.

\section{b. External involvement}

Pernyataan dengan nilai mean tertinggi untuk dimensi external involvement adalah "Saya membuat playlist di situs musik (misal Spotify, Joox, iTunes) yang berisi lagu-lagu idola saya" dengan nilai mean sebesar 4,06. Responden memiliki kecenderungan untuk setuju dengan pernyataan ini karena dengan membuat playlist, responden akan lebih dimudahkan untuk mengonsumsi konten idola mereka. Responden tidak perlu kesulitan mencari lagu idola mereka ketika hanya ingin menikmati lagu dari idola mereka saja.

Selanjutnya, pernyataan dengan nilai mean terendah adalah penyataan "Gaya berpakaian saya sehari-hari merepresentasikan idola saya" dengan nilai 2,18. Hal ini mengindikasikan bahwa responden memiliki kecenderungan untuk tidak setuju dengan pernyataan tersebut. Perbedaan budaya dan musim membuat responden kurang setuju. Di Korea, mode berpakaian akan terus berganti seiring musim dan terkadang tidak cocok jika diterapkan di Indonesia yang hanya memiliki 2 musim saja.

\section{c. Desire to acquire}

"Tergabung dalam fandom membuat saya ingin memiliki benda-benda yang terkait dengan idola saya (misal album, dvd konser, lightstick)" menjadi pertanyaan dengan nilai mean tertinggi pada dimensi ini dengan nilai 3,97. Para responden memiliki kecenderungan untuk setuju dengan pernyataan tersebut. Tergabung di dalam suatu fandom K-pop sedikit banyak membuat seseorang memiliki keinginan untuk melakukan pembelian barang-barang terkait idola mereka. Hal ini sesuai dengan dimensi desire to acquire di mana salah satu karakteristik fanatisme adalah adanya keinginan untuk membeli dan memiliki benda yang berkaitan dengan sang idola.

Sementara pernyataan dengan mean terendah adalah pernyataan "Saya tidak keberatan jika harus mengeluarkan uang untuk membeli benda-benda terkait idola saya" dengan nilai sebesar 3,16. Meskipun memiliki nilai mean terendah, bisa dikatakan bahwa responden tetap memiliki kecenderungan untuk setuju dengan pernyataan tersebut. Mengeluarkan uang untuk membeli benda-benda terkait sang idola bisa dikatakan sebagai salah satu wujud aktualisasi diri sebagai seorang fans. Dengan membeli, responden kemudian akan memiliki benda terkait idola sehingga mereka akan merasa menjadi bagian dari suatu fandom.

\section{d. Interaction}

Para responden memiliki kencenderungan untuk setuju denga pernyataan "Internet menjadi media saya untuk berinteraksi dengan fans lain di dalam fandom" tersebut dtunjukkan dengan nilai mean sebesar 4,29. Pernyataan tersebut merupakan pernyataan dengan nilai mean tertinggi. Tidak bisa dipungkiri bahwa hampir semua orang menggunakan internet termasuk responden menggunakannya untuk melakukan aktivitas fandom. Internet menghapus jarak antara responden dengan sang idola dan fans lain. Hampir semua konten tentang idola bisa didapatkan mealui internet dan berinteraksi dengan fans lain yang berbeda negara juga bisa dilakukan melalui internet. Hal tersebut menjadi latar belakang mengapa responden cenderung setuju dengan pernyataan tersebut.

"Saya pernah menulis surat dan mengirimkannya kepada idola saya melalui pos" menjadi pernyataan dengan nilai mean terendah, yaitu sebesar 1,83. Seperti yang disebutkan sebelumnya, internet menjadi media yang memudahkan fans untuk menjangkau idola mereka. Sama halnya dengan megirim surat yang jauh lebih mudah melalui surat elektronik. Responden tidak perlu repot membayar biaya pengiriman surat untuk sang idola. Maka dari itu, responden 
kurang setuju dengan pernyataan bahwa mereka pernah menulis surat dan mengirimkan kepada sang idola melalui pos.

\section{Uji Korelasi}

Uji korelasi dilakukan untuk melihat kekuatan hubungan kedua variabel. Dari analisis statistik yang telah dilakukan, didapatkan angka Pearson Correlation Test sebesar 0,663. Angka tersebut menunjukkan adanya korelasi positif yang kuat antara kedua variabel, di mana semakin tinggi kegiatan parasosial yang dilakukan oleh responden maka semakin tinggi pula nilai loyalitas responden terhadap sang idola. Peneliti kemudian melakukan uji korelasi antar dimensi tiap variabel dengan menggunakan Pearson Correlation Test.

Tabel 1

Hasil uji korelasi antar variabel

\begin{tabular}{|c|c|c|c|}
\hline & & Parasosial & Loyalitas \\
\hline \multirow[t]{3}{*}{ Parasosial } & $\begin{array}{l}\text { Pearson } \\
\text { Correlation }\end{array}$ & 1 & $.663 * *$ \\
\hline & $\begin{array}{l}\text { Sig. } \\
\text { tailed })\end{array}$ & &, 000 \\
\hline & $\mathrm{N}$ & 271 & 271 \\
\hline \multirow[t]{3}{*}{ Loyalitas } & $\begin{array}{l}\text { Pearson } \\
\text { Correlation }\end{array}$ & $.663 * *$ & 1 \\
\hline & $\begin{array}{l}\text { Sig. } \\
\text { tailed })\end{array}$ & ,000 & \\
\hline & $\mathrm{N}$ & 271 & 271 \\
\hline
\end{tabular}

Sumber: data kuesioner, diolah (2020)

Dari uji yang telah dilakukan, ditemukan bahwa nilai korelasi terbesar adalah antara dimensi behavioral dengan dimensi interaction. Nilai korelasi kedua dimensi tersebut adalah 0,564. Angka tersebut menunjukkan bahwa adanya korelasi yang kuat antara kedua dimensi tersebut. Sementara itu, nilai korelasi terkecil terdapat pada hubungan antara dimensi perceptual-cognitive dengan desire to acquire. Namun, dari angka korelasi sebesar 0,392, dapat diketahui bahwa kedua dimensi tersebut masih tetap memiliki hubungan yang cukup kuat.

Tabel 2

Hasil uji korelasi antar dimensi

Sumber: data kuesioner, diolah (2020)

\begin{tabular}{lcccc}
\hline & $\begin{array}{c}\text { Internal } \\
\text { Involve } \\
\text { ment }\end{array}$ & $\begin{array}{c}\text { Extern } \\
\text { al } \\
\text { Involv } \\
\text { ement }\end{array}$ & $\begin{array}{c}\text { Desire } \\
\text { to } \\
\text { Acquir } \\
\text { e }\end{array}$ & $\begin{array}{c}\text { Interact } \\
\text { ion }\end{array}$ \\
\hline Cognitive & $.420^{* *}$ & $.454 * *$ & $.392 * *$ & $.457 * *$ \\
Affective & $.402 * *$ & $.508^{* *}$ & $.491^{* *}$ & $.474 * *$ \\
Behavioral & $.446^{* *}$ & $.546^{* *}$ & $.495^{* *}$ & $.564 * *$ \\
\hline
\end{tabular}

\section{Analisis Krostabulasi}

Analisis yang selanjutnya dilakukan oleh peneliti adalah analisis krostabulasi yang dibagi menjadi beberapa bagian sebagai berikut. 


\section{Krostabulasi jenis kelamin}

Analisis ini mendapatkan dua pernyataan yang berkorelasi dengan jenis kelamin responden, yaitu "Saya mudah terbawa perasaan oleh apapun yang bias saya lakukan" dengan nilai chi-square sebesar 9,537 dan pernyataan "Saya sering memilih meninggalkan kewajiban dunia nyata saya untuk melakukan aktivitas fandom" dengan nilai chi-square sebesar 12,837. Chi-square hitung yang didapatkan tersebut bernilai lebih besar daripada nilai chi-square tabel sehingga kedua pernyataan tersebut berkorelasi dengan jenis kelamin.

\section{Krostabulasi usia}

Pada bagian ini, didapatkan 8 pernyataan yang berkorelasi dengan usia responden. Nilai chi-square tertinggi yang muncul dari kedelapan pernyataan tersebut adalah 118,516 yaitu pada pernyatan "Saat bias saya bahagia saya juga merasa bahagia, begitu juga saat bias saya sedih saya juga merasa sedih" dan pernyataan "Saya juga menggunakan foto profil media sosial yang merepresentasikan idola yang saya sukai" mendapatkan nilai chi-square hitung sebesar 93,592. Nilai chi-square hitung kedelapan pertanyaan tersebut berada di atas nilai chi-square tabel sehingga bisa dikatakan bahwa kedelapan pertanyaan tersebut berkorelasi dengan usia responden.

\section{Krostabulasi pengeluaran bulanan}

Analisis krostabulasi pengeluaran bulanan ini mendapatkan 6 pernyataan yang memiliki korelasi. Pernyataan dengan nilai chi-square hitung tertinggi untuk pernyataan yang berkorelasi adalah "Saya memahami aspek kepribadian bias saya yang sangat saya sukai atau tidak saya sukai" yaitu sebesar 69,447. Sementara pernyataan dengan nilai chi-square hitung terendah adalah "Saya menyukai bias saya karena prestasi mereka" yaitu sebesar 24,154. Keenam pertanyaan tersebut memiliki korelasi dengan pengeluaran bulanan responden karena nilai chisquare hitung yang muncul lebih besar dari nilai chi-square tabel.

\section{Krostabulasi fandom yang diikuti}

Analisis krostabulasi fandom yang diikuti responden menghasilkan 5 pernyataan yang berkorelasi. Kelima pernyataan tersebut dikatakan berkorelasi karena memiliki nilai chi-square hitung yang lebih besar daripada nilai chi-square tabel. Nilai chi-square hitung tertinggi yang didapatkan dari 5 pernyataan yang berkorelasi adalah pada pernyataan "Kadang-kadang, tanpa sadar saya mengucapkan sesuatu yang tertuju kepada bias saya" yaitu sebesar 183,673. Pernyataan dengan nilai chi-square hitung terendah adalah "Tergabung dalam fandom membuat saya ingin memiliki benda-benda yang terkait dengan idola saya (misal album, dvd konser, lightstick)" dengan nilai chi-square hitung sebesar 172,113.

\section{Krostabulasi dengan ada/tidaknya ultimate bias}

Pada analisis krostabulasi bagian ini, didapatkan 19 pernyataan yang berkorelasi. Nilai chisquare hitung dari 19 pernyataan tersebut lebih besar dari nilai chi-square tabel sehingga pernyataan-pernyataan tersebut dianggap memiliki korelasi. Dari 19 pernyataan yang berkorelasi, pernyataan "Saya dengan tekun mengikuti aktivitas bias saya" memiliki nilai chisquare hitung tertinggi yaitu sebesar 51,601. Sementara pernyataan "Saya tidak keberatan jika harus mengeluarkan uang untuk membeli benda-benda terkait idola saya" mendapatkan nilai chi-square hitung terendah, yaitu sebesar 10,276.

\section{KESIMPULAN}

Dari hasil penelitian dan pembahasan yang sudah dijabarkan, dapat ditarik kesimpulan bahwa ditemukan hubungan yang signifikan antara parasosial dengan loyalitas fans. Hubungan tersebut ditemukan dari hasil uji korelasi yang menunjukkan adanya hubungan positif dari kedua variabel tersebut. Hubungan tersebut ditunjukkan dengan angka Pearson Correlation Test sebesar 0,663 sehingga bisa dikatakan bahwa hubungan kedua variabel adalah hubungan yang kuat. 
Penelitian mengenai fans, audiens, dan fandom yang bekaitan dengan K-pop mulai menjamur, namun penelitian mengenai hubungan parasosial dengan para idola belum banyak ditinjau. Penelitian lanjutan dapat menganalisa mengenai hubungan parasosial yang tercipta antara idola K-pop dengan berbagai perilaku fans Indonesia misalnya berkaitan dengan gaya hidup, minat pembelian, dan lain sebagainya.

\section{DAFTAR PUSTAKA}

Aaker, J. (1991 ). The negative attraction effect? A study of the attraction effect under judgment and choice. ACR North American Advances.

Abu-Alhaija, A. S., Hussein, H. S., \& Allan, A. J. (2019). Relationship between Customer Satisfaction and Customer Loyalty: A Review and Future Directions of its Nature and Approaches. Eurasian Journal of Social Sciences, 7(4), 28-39.

Alok, K., \& Srivastava, M. (2013). The antecedents of customer loyalty: an empirical investigation in life insurance context. J. Competitiveness 5 (2) , 139-163.

Audi, M., Masri, R. A., \& Ghazzawi, K. (2015). The effect of celebrity endorsement on creating brand loyalty: An application on the Lebanese cosmetic sector's demand. International Journal of Business Management and Economic Research, 6(5) , 273-287.

Chung, E., Farrelly, F., Beverland, M. B., \& Karpen, I. O. (2017). Loyalty or liability. Marketing Theory, 18(1) , 3-30. doi:10.1177/1470593117705696.

Chung, S., \& Cho, H. (2017). Fostering Parasocial Relationships with Celebrities on Social Media: Implications for Celebrity Endorsement. Psychology \& Marketing, 34(4) , 481-495. https://doi-org.proxy006.nclive.org/10.1002/mar.21001.

Chung, S., \& Cho, H. (2014). Parasocial relationship via reality TV and social media: its implications for celebrity endorsement. . In Proceedings of the ACM International Conference on Interactive Experiences for TV and Online Video, (pp. 47-54).

De Guzman Centeno, D. (2016). Parasociality and Habitus in Celebrity Consumption and Political Culture. Asian Journal of Social Science, 44(4-5) , 441-484. doi:10.1163/1568531404404002 .

Dibble, J. L., Hartmann, T., \& Rosaen, S. F. (2016). Parasocial interaction and parasocial relationship: Conceptual clarification and a critical assessment of measures. Human Communication Research, 42(1) , 21-44.

Ehsan, U., Warraich, K. M., \& Sehribanoglu, S. (2016). Measuring brand loyalty in cola market: A three dimensional approach. Journal of Social Sciences, 9(1) , 153-165.

Erdem, T., \& Swait, J. (1998). Brand equity as a signaling phenomenon. Journal of consumer Psychology, 7(2) , 131-157.

Frederick, E. L., Lim, C. H., Clavio, G., \& Walsh, P. (2012). Why we follow: An examination of parasocial interaction and fan motivations for following athlete archetypes on Twitter. International Journal of Sport Communication, 5 , 481-502.

Fuschillo, G. (2020). Fans, fandoms, or fanaticism? Journal of Consumer Culture, 20(3) , 347-365. doi:10.1177/1469540518773822 .

Groene, S. L., \& Hettinger, V. E. (2016). Are you "fan" enough? The role of identity in media fandoms. Psychology of Popular Media Culture, 5(4), 324. 
Han, H., Nguyen, H. N., Song, H., Chua, B.-L., Lee, S., \& Kim, W. (2018). Drivers of brand loyalty in the chain coffee shop industry. International Journal of Hospitality Management, 72 , 8697. doi:10.1016/j.ijhm.2017.12.011.

Hartmann, T. (2016). Parasocial interaction, parasocial relationships, and well-being. In L. Reinecke, \& M. B. Oliver, The Routledge handbook of media use and well-being: International perspectives on theory and research on positive media effects (pp. 131-144). Routledge.

Hartmann, T., \& Goldhoorn, C. (2011). Horton and Wohl revisited: Exploring viewers' experience of parasocial interaction. Journal of communication, 61(6) , 1104-1121.

Hoffmann, N. (2013). Loyalty schemes in retailing: a comparison of stand-alone and multi-partner programs. Peter Lang International Academic Publishers.

Horton, D., \& Wohl, R. (1956). Mass communication and para-social interaction: Observations on intimacy at a distance. Psychiatry, 19(3) , 215-229.

Horton, D., \& Wohl, R. (1982). Mass Communication and Para-Social Interaction: Observations on Intimacy at a Distance. Drama in Life: The Uses of Communication in Society , 212-227.

Hung, K., Chen, K., \& Tse, C. H. (2011). Assessing Celebrity Endorsement Effects in China: A Consumer-celebrity Relational Approach. Journal of Advertising Research 51 (4) , 608623. doi:10.2501/JAR-51-4-608-623.

Jenol, N. A., \& Pazil, N. H. (2020). Escapism and motivation: Understanding K-pop fans well-being and identity. Geografia-Malaysian Journal of Society and Space, 16(4) , 336-347.

Kim, M. S., \& Kim, H. M. (2017). The effect of online fan community attributes on the loyalty and cooperation of fan community members: The moderating role of connect hour. Computers in Human Behavior, 68 , 232-243.

Kim, M., \& Kim, J. (2020). How does a celebrity make fans happy? Interaction between celebrities and fans in the social media context. . Computers in Human Behavior, 106419 , 1-11. doi:10.1016/j.chb.2020.106419.

Kotler, P., \& Keller, K. L. (2012). Manajemen Pemasaran Edisi 12. Jakarta: Erlangga.

Labrecque, L. I. (2014). Fostering consumer-brand relationships in social media environments: The role of parasocial interaction. Journal of Interactive Marketing, $28,134-148$.

Marwick, A., \& Boyd, D. (2011). To see and be seen: Celebrity practice on Twitter. Convergence, $17(2), 139-158$.

Picon, A., Castro, I., \& Roldan, J. L. (2014). The relationship between satisfaction and loyalty: A mediator analysis. Journal of Business Research, 67(5) , 746-751. https://doi.org/10.1016/j.jbusres.2013.11.038.

Rasmussen, L. (2018). Parasocial interaction in the digital age: An examination of relationship building and the effectiveness of YouTube celebrities. The Journal of Social Media in Society, 7(1) , 280-294.

Reichheld, F. F. (1996). Learning from customer defections. Harvard business review, 74(2) , 5667. 
Reinartz, W. J., \& Kumar, V. (2000). On the profitability of long-life customers in a noncontractual setting: An empirical investigation and implications for marketing. Journal of marketing, 64(4) , 17-35.

Samra, B., \& Wos, A. (2014). Consumer in sports: Fan typology analysis. Journal of Intercultural Management. 6(4) , 263-288. doi: 10.2478/joim-2014-0050.

Schramm, H. (2015). Parasocial Interactions and Relationships. In W. Donsbach, The concise encyclopedia of communication (pp. 438-439). John Wiley \& Sons.

Schramm, H., \& Hartmann, T. (2008). The PSI-Process Scales. A new measure to assess the intensity and breadth of parasocial processes. Communications, 33(4) , 385-401.

Seregina, A. (2011). Fanaticism - Its development and meanings in consumers' live. (Disertasi Aalto University) , Diakses dari http://epub.lib.aalto.fi/en/ethesis/pdf/12738/hse_ethesis_12738.pdf.

Shoffner, L. K. (2019). Parasocial Relationship Influence on CoverGirl Buying Intentions: Trust and Loyalty from SMI and Celebrity Endorsements. In (Doctoral dissertation, Appalachian State University).

Sitasari, N., Rozali, Y., Arumsari, A., \& Setyawan, D. (2019). Self-Esteem And Celebrity Worship In Social Network Bollywood Mania Club Indonesia Members In Jakarta. Proceedings of the 1st International Conference on Business, Law And Pedagogy, ICBLP 2019. European Alliance for Innovation (EAI).

Sokolova, K., \& Kefi, H. (2020). Instagram and YouTube bloggers promote it, why should I buy? How credibility and parasocial interaction influence purchase intentions. Journal of Retailing and Consumer Services, 53, 101742 .

Stever, G. S. (2017). Parasocial Theory: Concepts and Measures. The International Encyclopedia of Media Effects , 1-12. doi:10.1002/9781118783764.wbieme0069.

Sulianti, A., Lubis, F. S., Az-Zahra, F., \& Hambali, A. (2018). Can emotional intelligence restrain excess celebrity worship in bio-psychological perspective? IOP Conference Series: Materials Science and Engineering (Vol. 434, No. 1, p. 012137) (pp. 1-5). IOP Publishing. doi:10.1088/1757-899X/434/1/012137.

Wilkie, W. L. (1994). Consumer Behavior, 3rd Edition. USA: John Wiley \& Sons, Inc. 